\title{
Ideology and policy in China in the era of reform, 1978-1986
}

STUART R. SCHRAM

School of Oriental and African Studies, London

Political developments in China during the decade since the death of Mao Zedong form the theme of the following analysis; particular emphasis is laid on reform of the economic and political system, as it has been advocated, and to some extent put into practice, since the Third Plenum of the Eleventh Central Committee in December 1978.

The Third Plenum was the fountainhead for nearly all the new trends which have emerged since. This presentation is divided into three parts: (1) from 1978 to the adoption of the Decision on Economic Reform in October 1984; (2) the problems and contradictions encountered in the application of these policies during the ensuing year and a half, from late 1984 to early 1986; and (3) the situation since the spring of 1986 and the prospects for the future.

\section{From the Third Plenum of 1978 to the Third Plenum of $1984^{1}$}

It is perhaps worth recalling, as a brief introduction, that Mao was not, in principle, hostile to economic development, nor did he object to the concept of "modernization". On the contrary, he freely used the term (jindaihua, xiandaihua) from the 1940s to the 1960s. During his last two decades, however, while he continued to stress the importance of economic progress, his increasing anxiety about the corrupting effects of prosperity, and of inequality, led him to adopt a series of radical policies which, in the end, proved self-defeating. The Great Leap Forward resulted in economic disaster and starvation, and the so-called "Great Proletarian Cultural Revolution" tore the fabric of society apart. Thus, when he died in September 1976, Mao left China in a parlous state. His successors, first Hua Guofeng and then Deng Xiaoping, have had to struggle with the problem of rescuing the country from this situation.

Hua Guofeng's solution was to follow a "two-track" policy. On the one hand, he pursued a grandiose programme of modernization and import of foreign technology, before China was either ready to use it or able to pay for it. But he did this behind a screen of Maoist and Cultural Revolution slogans, 
thus trying to please both the "left" and the "right" of the Party. (He also tried to emulate Mao in building up his own cult.)

Hua summed up his political views in the famous slogan of the "two whatevers": whatever words Mao had uttered were sacred, and whatever examples he had set must be followed forever. A crucial role in the struggle against the "Whateverists" was played by three great debates during the year 1978. The first, on the topic "Practice is the sole criterion for testing truth", meant in effect that results were more important than dogma. The second, about the appropriateness of the criterion of remuneration according to work in a socialist society, implied the negation of the egalitarianism which had prevailed, to a very substantial degree, since 1958, with Mao's personal support. The third, about the need to observe objective economic laws, contradicted Mao's view that the masses, when mobilized under the guidance of his thought, could do anything, overcoming all material difficulties.

By the end of 1978, the situation had progressed to such a point that, at the Third Plenum in December, Deng Xiaoping was able to obtain approval for the "responsibility system" in economic work, which has, as is well-known, been the cornerstone of China's reform policies ever since. This principle, which began to receive concrete application in the countryside in 1979, had a dual thrust. On the one hand, it was plainly anti-egalitarian.

On the other hand, it implied a growing role for the market. Hua Guofeng was replaced as Chairman in mid-1981, and in September 1982 ceased to to be even a member of the Politburo, remaining simply an ordinary member of the Central Committee. The era of Deng Xiaoping had begun, though he did not, like Mao and Hua, become Chairman, and the post itself was abolished.

Deng Xiaoping was, and remains, committed to the progressive and radical reform of the Chinese economy, and he believes that this reform must be accompanied by the "liberation of thought", the smashing of "forbidden zones", and the strengthening of democracy and the legal system which he demanded in December 1978 at the Third Plenum. But while he regards the creation of a freer atmosphere as essential to modernization, there are both "external" and "internal" limits to the extent or kind of freedom or democracy he is prepared to accept.

By "external" limits I mean limits set by the balance of forces within the Party, and expecially within the top leadership. In my view Chinese politics since 1978 should not be seen in terms of clearly defined and well-organized factions. There are, however, quite obviously sharp differences of opinion within the leadership, and alliances have progressively taken shape based on 
these differences. When a large number of his colleagues are worried by the consequences of his policies, Deng cannot afford to proceed uncompromisingly with these policies.

But at the same time, Deng Xiaoping is assuredly not, as he is sometimes called in the West, a "pragmatist". He is a veteran revolutionary, who believes in the dictatorship of the proletariat, the vanguard role of the Party, and a certain number of moral values he learned during the Yan'an period. When, therefore, free discussion, or relatively free local-level elections, appear to be developing a momentum which threatens Party control, he himself feels obliged (quite apart from what other leaders may think) to call a halt. The limitations set by the ideas or instinctive reactions of Deng Xiaoping himself and of other partisans of reform to their own actions are called "internal" limits on reform.

This point is sufficiently well documented from the record of Deng's words and deeds, in the zig-zag course of events during the past eight years. In December 1978 he gave, informally at least, his blessing to "Democracy Wall", but three months later, in March 1979, he himself drew a line by setting up the "four basic principles" of support for the socialist road, the dictatorship of the proletariat, the leadership of the Party, and Marxism-Leninism and Mao Zedong Thought. His theoretical spokesmen have made it quite plain that he did so partly because, only three months after the Third Plenum, he was still vulnerable to attack from Hua Guofeng and the "Whateverists", but at the same time there is no doubt that he himself believes in these four principles, and had lost patience with the unofficial "democracy movement".

Similarly, Deng Xiaoping made, in August 1980, a remarkable speech about the need for the "democratization" (minzhuhua) of the Party and state leadership systems, in which he blamed the "excessive powers" assumed by Mao Zedong not only on the old Chinese tradition of "feudal autocracy", but on patterns established by the Comintern. Some of his spokesmen, such as Liao Gailong, even traced the source of these errors to Lenin himself. But then, after the arrest of most of the remaining leaders of the "democracy movement" in the spring of 1981, Deng took the lead in the criticism of the writer Bai Hua. In this case, too, he was no doubt moved by both "internal" and "external" constraints. He probably did not like Bai Hua's "Bitter Love", but the tightening of controls in 1981 was manifestly linked to the phase of "consolidation" in the economic reforms which Deng had announced in December 1980, and which probably did not reflect so much his own instincts as the reticence of others in the leadership regarding the dismantling of the old-style commandtype economy and the introduction of a greater role for the market. 
This interplay between "internal" and "external" factors became much plainer in the case of the third cycle of loosening and tightening of controls, in 1982-1983. The Twelfth Congress in September 1982 saw a strengthening of the position of Deng Xiaoping, Hu Yaobang, Zhao Ziyang and other likeminded figures within the top leadership, and a renewed stress on democratic reform, side by side with the call to build "socialist spiritual civilization". But then, in the autumn of 1983, there emerged the curious affair of the campaign against "spiritual pollution".

In the spring of 1983, the line of the Chinese Communist Party was marked by three propositions which still today, to a large extent, characterize the overall trend of Chinese politics. There was first of all the slogan "Carry out reform resolutely, but in proper order" (jianjue, er you zhixu de gaige). Both halves of this were and are important. There must be no turning back in the reforms, but at the same time they must not be allowed to get out of control. The second point was the stress on knowledge, the assimilation of the most modern high technology, and going beyond that, the call to promote intellectuals to positions of authority, and not merely to use them as advisers or experts. Thirdly, there was in early 1983 the clear statement, constantly repeated, that "leftism" was the main danger, and that leftists in the Party must be made to reform, or eliminated from leading posts.

In September-October 1983, at the Second Plenum of the 12th Central Commitee, Deng Xiaoping and Chen Yun jointly put forward a demand to carry out extensive ideological work aimed at eliminating what was called "spriritual pollution". This "work", which soon developed in fact into something very much like the "campaigns" (yundong) which had taken place in Mao's day, had two main targets. At the level of upper and middle-level cadres and intellectuals, it was directed against insufficiently orthodox ideas, especially at the theories about humanism, and about the existence of alienation under socialism, put forward by Zhou Yang, Wang Ruoshui and others. At the grass roots, it became an attack on foreign influences and on all sorts of "depraved" behaviour, especially in the sexual domain, and also on the activities and life style of those who had followed Deng Xiaoping's injunction to enrich themselves in the context of the responsibility system.

Why did Deng Xiaoping initially approve this campaign, and why did he subsequently call a halt to it? Undoubtedly he launched it in part because, as already observed, he is a veteran revolutionary who genuinely believes in Marxist ideals, and in the "revolutionary spirit" inherited from Yan'an, and does not want them called into question by too much enthusiasm for "bour- 
geois liberalism", individualism, and other wrong ideas. But it is certainly no accident that this campaign was started simultaneously with the beginning of the "Rectification Campaign" in the Party aiming primarily at rooting out Cultural Revolution leftists. At a time when he was attacking the left, Deng assuredly did not want to be seen by those worried about this purge as "soft on capitalism".

The reasons for the abandonment of the campaign against "spiritual pollution" in March 1984 are even clearer. The political climate which had developed in this context, and especially the attacks on those who had "become rich first" and the confiscation of their wealth in some cases, was badly disrupting the work on the reform and development of the economy, which Deng Xiaoping regarded as of primary importance. He therefore refused to authorize the open publication of his September 1983 speech on "spiritual pollution", for fear of prolonging and intensifying the campaign, and stopped the campaign abruptly. In this context, there is great symbolic significance in his visit to Shenzhen, in February 1984. On his return to Beijing, he talked with senior comrades, and expressed his enthusiasm for the "open policy" in general, and the special economic zones in particular. They were, he said, a window for importing both foreign technology and foreign techniques of management. He endorsed the slogan current in Shenzhen, "Time is money". (I do not know whether or not he was aware that this slogan was originally coined by the American capitalist J.P. Morgan.) It was right, he said, for some areas such as this to become rich first. "Egalitarianism will not work."

There followed, in March and April, a shift in economic policy not only toward the reaffirmation of the responsibility system in the countryside, but toward its much more sweeping extension to industry and the cities. This went hand in hand with the re-definition of the main enemy as, once again, "leftism" rather than rightism or bourgeois influences. Hu Yaobang played a very important role in this respect; the editorial of People's Daily on 1 April 1984, which was in fact a summary of a talk by Hu, declared that, in the aftermath of the Great Leap Forward and the Cultural Revolution, it would take years of work to root out the leftist poison. The entrepreneur, whether he be the enterprising peasant who gets rich first in the countryside, or the manager of a collectively-owned factory in the city, was hailed as the hero of the present age.

The seal was set on this new upsurge of reform at the Third Plenum of the 12th Central Committee in October 1984. Like the Third Plenum of the 11th Central Committee in December 1978 which had started the whole process, this meeting was important because of the political line it adopted, rather than 
because of any precise and detailed policy decisions. The crucial point was that the Chinese economy was explicitly defined as a "planned socialist commodity economy". Henceforth, theoretical discussions of commodities and of the role of the market would be regarded as completely legitimate, contrary to the situation in 1980-81, when Chen Yun's ideas of the market as a "bird" in the "cage" of the planned economy predominated. The Decision adopted by the Central Committee on this occasion called for devolving "decision-making power" to enterprises. It also spoke out once again against egalitarianism, and stressed that the open-door policy would be maintained.

\section{From October 1984 to the adoption of the Seventh Five-Year Plan}

The end of the year 1984 was marked by a high tide of free discussion and of criticism of dogmatism in all its forms. The famous article in People's Daily of 7 December 1984 entitled "Theory and Reality"., ${ }^{3}$ which was widely interpreted outside China as a repudiation of Marxism, did not in fact say any such thing. It simply stated the view, which had been advanced many times since the hundredth anniversary of Marx's death in 1983, that he had lived a long time ago, and that all of today's problems could not be solved merely by referring to his works on the shelf. The point was, however, stated very strongly in the article of 7 December, and was given added authority by the fact that this article, like that of 1 April 1984, was a summary of a talk by Hu Yaobang. Thus, while Marx and Marxism were in no sense to be abandoned, they were to be interpreted flexibly, and new ideas developed to deal with the problems of the present age.

The end of December 1984 also saw the call by Hu Qili, widely regarded as Hu Yaobang's probable successor, at the congress of the Writers' Association, for "ample" (chongfen de) creative freedom. ${ }^{4}$ But at the same time, in late 1984, prices were rising steeply, the economy was "overheating", credit was being expanded recklessly, and above all the so-called "evil winds" or "unrighteous winds" (buzheng zhi feng) of corruption and abuse of privilege were beginning to blow. According to later accounts, the Central Committee took note of these problems as early as December 1984; in February and March 1985 it began to act against such tendencies. The main problems raised were polarization, and the threat of the emergence of a new bourgeoisie; speculation and black market transactions; and above all the misuse of official positions to engage in business through intermediaries. 
Deng Xiaoping, Hu Yaobang, and others sharply denounced these phenomena in February and March 1985, but at the same time they stressed that measures against such "unrighteous winds" were indispensable precisely because, if these negative side effects were not eliminated, the reforms themselves, which Deng Xiaoping characterized in March 1985 as a "second revolution", equal in importance to that of $1949,{ }^{5}$ would be compromised.

The ambiguity of the situation, and the difficulty of analyzing developments simply in terms of "factions", is illustrated by contradictory attitudes in the spring of 1985. Thus Hu Qiaomu, who had been the "backstage boss" of the campaign against spiritual pollution (with Chen Yun's support), wrote in April 1985 that Marxism must take into account information theory, that the previous system making socialism a "huge cartel with all workers being its staff members" would not work, and that the individual "may play a positive role in society, and even in socialist society" ${ }^{6}$ While this relative conservative was making statements such as these, $\mathrm{Hu}$ Yaobang, who had refused to have anything whatsoever to do with the "spiritual pollution" campaign of 198384, made a relatively hard and doctrinaire speech on journalism in February 1985, and had this openly published, thus adding to its impact, in April 1985. He said that journalism was not like literature, and could not enjoy the same freedoms, for it was the mouthpiece of the Party. It was right to oppose "spiritual pollution", though one shouldn't talk about it too much.7 Thus both wings of Party opinion appeared to be shifting toward the middle, or toward a certain common ground.

The September 1985 Party Conference saw what can only be characterized as a stand-off between the two powerful old men, Deng Xiaoping and Chen Yun. Their speeches were not wholly contradictory, but the emphasis was quite different. Deng said, in effect, that while there were negative effects of the new policies, such as economic crimes, etc., and these must be combatted, the reforms themselves, and the opening to the outside world, must be pushed boldly forward. Chen Yun stressed rather the negative consequences of the reforms, and the need to strengthen ideological work, and to reinforce the prestige of the organs concerned with propaganda. ${ }^{8}$

During the half-year following the Conference of autumn 1985 problems continued to manifest themselves. The Chinese leadership had to surmount difficulties caused by the lack of experience, not only in China, but in any communist-ruled country, in operating a system with as extensive a role as this for the market. The problem of inflation in prices for consumer goods, especially in the cities, was particularly acute. And yet, the impulse toward 
reform, and the key ideas accompanying the reform, survived.

In its New Year editorial on 1 January 1986, People's Daily called for a relative pause for consolidation, after a bold step forward last year, but also for the testing of new ideas, with a view to a new big advance in reform next year." On Chinese New Year, 9 February, it was proclaimed that "we must be bold as tigers in this Year of the Tiger". ${ }^{10}$ For his part, Du Runsheng, in his report on rural work published at the end of January, said categorically that egalitarianism must be utterly repudiated - "to deny the need for differences in rewards is to negate the reforms themselves". ${ }^{11}$ There was, however, very little indeed said about the theories or broad principles of the new society which is being shaped by the reform.

In the spring of 1986, this situation suddenly changed, and the Chinese began speaking of the need for a comprehensive theoretical framework to define the nature of the new system which is emerging. It might seem to foreigners that whether or not there is a theory about China's reforms is of little practical importance, though the Chinese may worry about the problem because of their need to reconcile their practice with Marxism. In my view, the call for a systematic theoretical analysis will, on the contrary, have considerable influence on the scope and on the stability of the reforms.

It is important, in any case, to underscore the difference in this respect between 1986 and 1984. In 1984, when the campaign against "spiritual pollution" was suddenly halted, the opponents of this witch-hunt did not launch a theoretical counter-offensive. Instead, they shifted the ground of controversy from theory to practice, and argued very forcefully that the new policies based on material incentives, the decentralization of authority, and the negation of the egalitarianism of the Cultural Revolution would work, and would rapidly bring prosperity not only to a few successful entrepreneurs, but to the whole country. There was, on the other hand, no attempt to explain the kind of society which these reform would produce. There are two apparent reasons for this, which are probably complementary rather than mutually exclusive. First, Deng Xiaoping and the promoters of reform no doubt did not know at the outset exactly where they were going. They wanted to shake up the old system, breathe new life into the economy, and then see what happened. Secondly, there may well have been the fear that, if the blueprint were drawn up, it would look too much like the "restoration of capitalism" which some leftists in other countries (and also in China) think is under way. Deng Xiaoping is, of course, quite certain that a "planned socialist commodity economy" is a more efficient way of running a socialist country, and not a return to capitalism. But 
despite collective ownership of the means of production, the degree of income differentiation, the appeal to entrepreneurial instincts, and above all the legalization, within certain limits, of hired labour, raise many questions.

The anxieties existing just below the surface were dramatically illustrated by the incident, in December 1985, of the article by a young Chinese scholar called Ma Ding, in which foreign newspapers played a not altogether creditable role. His discussion of how Chinese economists were trying to make use of positive elements in Western economic theories ${ }^{12}$ was presented by Asahi Shimbun as a repudiation of Marx in favour of Keynes, just as the People's Daily editorial of 7 December 1984 had been widely seen abroad as a negation of Marx. This misinterpretation was further distorted by a Chinese-language newspaper published in New York, the Zhongbao. And in this case, too, the author of the article was, as a result, blamed for the confusion, and subjected to criticism in China, especially by doctrinaire ideologists such as Deng Liqun and $\mathrm{Hu}$ Qiaomu.

This time, however, people high up in the Chinese Communist Party appear to have decided that the continuing uncertainty about the shape of the emerging new order was more dangerous than attacking the problem squarely. The way to such an approach was no doubt opened by an as yet unpublished speech by $\mathrm{Hu}$ Yaobang at the very beginning of 1986. In it, Hu noted the decline of the people's faith in Marxism not only in China, but throughout the world. Calling for an examination of the ideological inadequacies and political errors leading to this long-term development, Hu urged the Chinese to search for innovative answers to new problems so as to reverse the trend. ${ }^{13}$

In late March 1986, a writing group of the Chinese Academy of Social Sciences published an article in People's Daily stating that the many problems encountered, in the last two years especially, in implementing the Sixth FiveYear Plan, resulted, among other causes, from the fact that "theoretical preparation was extremely inadequate" ${ }^{\prime 14}$ During the ensuing weeks, the message that the time had now come to remedy this, and to produce a comprehensive new theory based on China's experience of "commodity socialism", was authoritatively proclaimed. Many of the most striking new formulations were advanced during the period when the Seventh Five-Year Plan was under consideration by the National People's Congress, or immediately afterward, some of them in the Plan itself, or in Zhao Ziyang's report introducing it. 


\section{Theory and Practice in the Period of "Replacing the Old System by the New"}

The idea of a change in the system, economic and ultimately political as well, features prominently in the Plan, where it is stated in the terms cited above: "replacing the old system by the new" (xinjiu tizhi zhuanhuan). Broadly it may be noted that the targets, and the annual rate of increase in the production of all sectors of the economy, have been deliberately scaled down, not only to avoid negative economic and financial side-effects, but above all to create a suitable climate for further structural reforms.

It is this political dimension of the Seventh Five-Year Plan which I feel competent to analyse, and about which I will now make some comments. The first, and in some ways the most significant point is the clear statement, in the opening section, that of the three tasks - reform, economic growth and technological progress, and improving living standards - reform is the most important. This objective is formulated as follows:

Take a further step forward in creating, by reform of the economic structure, a favourable economic and social environment, strive to maintain a basic balance between total social demand and supply, thus enabling the reform to unfold more successfully, and work hard to lay the groundwork for a new type of socialist economic structure with Chinese characteristics within five years or a little longer.

As for the content of these ongoing structural reforms, there are three main points: to strengthen the decision-making powers of individual enterprises, to increase the role of the market, and to exercise state control more and more by indirect rather than direct means. In some respects, the content and even the language of the Plan follow fairly closely those of the Decision of October 1984, but in other respects the Plan marks a step ahead. For example, the section on structural reform contains the following passage:

We shall further streamline government administration and delegate more power to lower levels. Except for a few special government departments and industries, no ministries, provinces, or autonomous regions will exercise direct control over enterprises. City government functions must be separated from those of enterprises so that enterprises will become relatively independent socialist commodity producers and dealers, with full authority over their own management and full responsibility for their own profits and losses. 
The formulation just quoted, calling for the emergence of "independent socialist commodity-producing enterprises", echoes almost exactly the 1984 Decision, but the emphasis is today placed more strongly on extending the scope of the responsibility system, and above all on reducing the role of mandatory planning. ${ }^{15}$ Price differentials between high-grade and ordinary products will be increased, in order to make greater use of the regulating function of prices, and generally speaking the emphasis in economic development will be shifted toward quality, rather that mere quantity.

This point, of course, is closely linked to the call for increasingly rapid technological progress, in order to catch up with advanced world levels. The importance of high technology has been emphasized in China for a number of years, but it is stressed, if possible, even more in the new Five-Year Plan. At the same time, the importance both of education, and of exchanges with foreign countries, in promoting the introduction of the most modern technology is dealt with at considerable length, in the Plan itself, and in Zhao Ziyang's report.

Zhao Ziyang refers to what he called the "strategic role" of progress in education and science in adapting to the ongoing process of technological change. This obvious point needs no further comment, except that, unlike some Western countries, including Britain, China places stress both on applied and on basic research. ${ }^{16}$

The aspects of the Seventh Five-Year Plan discussed above refer explicitly to reform of the economic system, but it is quite evident that they have political implications as well. Just how important these are is symbolized by the term used to characterize the next five years: "the period of replacing the old system by the new". The statement that the whole of the "old system" was in the process of being replaced by a new order, and the calls for the elaboration of a comprehensive theory defining that new order, were plainly extremely worrying to those who felt that reform was going too far too fast, and threatened to get out of hand.

Just as the Decision of October 1984 required all Party members, whatever their own ideas, to accept henceforth that China had a "planned socialist commodity economy", so the publication of authoritative articles spelling out in more detail what is meant by "socialism with Chinese characteristics" would make it much more difficult to argue for the reversal of current policies. ${ }^{17}$

Early in 1986, influential figures in the leadership still devoted to Leninist doctrine as it has long been understood, such as Hu Qiaomu and Deng Liqun, were seeking to make of such ideological issues the main topic of discussion at 
the forthcoming Sixth Plenum of the Central Committee, then scheduled for June 1986. Had som of the old dogmas thus been formally reasserted by the Party, the conservatives rather than the reformers would have been in a position to take advantage of the principle of "democratic centralism" which limits the scope for public dissent once a view has been openly adopted. In effect, the partisans of such ideas, backed by Chen Yun at the very top, were trying to hold, after a two-year delay, the conference on ideology and "communist ideals" which had originally been fixed for the spring of 1984, but had been quietly shelved after the collapse of the campaign against "spiritual pollution".

Once again, however, their efforts were frustrated. By April, the agenda for the Sixth Plenum (which finally met only in September) had been changed to deal not with "thought" or "ideology" (sixiang), a code word for fidelity to Leninist dogmas, but with the much vaguer and less controversial topic of building "socialist spiritual civilization".

Plainly, Hu Yaobang had this controversy in mind when on 9 April 1986 he addressed the problem of "contradictions within the Party", ${ }^{18}$ thereby revealing the existence of divergent views at the highest levels of the Party. This speech was openly published only in July, but in mid-April, during a visit to the Taihang Mountains, Hu put the same points even more bluntly, remarking:

There are some comrades who do not recognize that there are contradictions within the Party. In reality, there are contradictions in everything that exists in the world, and everything develops amidst contradictions and the resolution of contradictions. We must not fear contradictions within the Party, and we must not evade them. The contradictions within the Party are for the most part the result of differing views about our work and about our understanding of the situation. Under normal circumstances, such contradictions are not antagonistic, and can very well be resolved. We should use the methods of exchange of ideas, democratic consultation, private talks, and mutual understanding and tolerance. If we use the correct methods, we need not fear trouble, and we need not fear democracy (buyao pa mafan, buyao pa minzhu). ${ }^{\text {is }}$

In raising the issue of contradictions within the Party in this way, Hu Yaobang appears to have had two aims: to reassure, and to warn. By stressing that differences of opinion should be resolved by "private talks, and mutual understanding and tolerance", he signalled that there was to be no witch-hunt, and 
that the partisans of reform wished to unite all members of the leadership around an agreed policy line. But at the same time, it was made crystal clear, both in Hu's speech and in other statements last spring, that in the last analysis the reform process would be pushed forward vigorously, and that those who had doubts about it would have to fall into line.

In any case, the fact that since the spring of 1986 the balance has been tilted more and more in favour of the "reformers" in China results in significant degree from the support which such views have received from the very top of the Party hierarchy. In late April, on a visit to Shanghai, Hu Qili encouraged social scientists to take advantage of the blow which had been dealt by the reforms to outmoded ideas, develop new theories in the light of current problems, and play their full role as the "think tank of the Party and the government" ${ }^{\prime 20}$ This emphasis on the importance of the social sciences in analyzing the effects of the reforms was already to be found in the Seventh Five-Year Plan (par.27). ${ }^{21} \mathrm{~A}$ few days later, the new Head of the Propaganda Department of the Central Committee, Zhu Houze, held a meeting on 22 April with theoretical workers, journalists, and those in charge of social science institutes, at which he called on them to study thoroughly the laws of a socialist commodity economy in all of their ramifications, and thus to facilitate the development of the reforms. There was no precedent or model for the reforms, he said, and there must therefore be new breakthroughs (tupo) on the theoretical level. In carrying out this task, he added, social scientists, while holding to the "four basic principles", should think for themselves, put forward different views and argue them in a relaxed atmosphere, in accordance with the policy of a "hundred flowers and a hundred schools". ${ }^{22}$

A number of those Zhu Houze addressed on 22 April had, in fact, already taken this injunction to heart. A large part of the 21 April issue of the Shanghai World Economic Herald (Shijie jingji daobao) was devoted to the call for theoretical breakthroughs to accompany and support the reforms. The lead article by Su Shaozhi argues that these breakthroughs must include breaking with certain ideas and conclusions of Marx himself, while remaining true to the Marxist method. Marx, Su points out, made extensive use of bourgeois economic works; the critical assimilation of ideas from all quarters is therefore an integral part of Marxism. The Chinese reforms are, according to Su, the first serious attempt since Stalin put an end to Lenin's New Economic Policy to devise a method for building socialism different from the Stalinist model, which had been applied in China for over thirty years. Quite clearly, since China began Soviet-style economic development only in 1953, the reference to "over 
thirty years" means from 1953 to the decision of October 1984. Reform itself, said $\mathrm{Su}$, is a breakthrough, and must therefore involve constant theoretical exploration and ruptures with past dogmas. ${ }^{23}$

The World Economic Herald had, in fact, reprinted Ma Ding's contentious article, referred to above, two weeks previously. ${ }^{24}$ There is an interview with Ma Ding himself on the first page of the 21 April issue, and several contributors, including Yu Guangyuan, stress the positive effect which the article has had in provoking a debate, and thereby giving rise to a new upsurge of the "Hundred Flowers" policy, launched exactly thirty years ago, in May 1956, and then prematurely abandoned. Those who criticize Ma.Ding's article as "anti-Marxist" and as a form of "spiritual pollution" are, these authors argue, "Whateverists" of Marxist dogma, unwilling to take account of changing reality, not real disciples of Marx. ${ }^{25}$ Moreover, although the Five-Year Plan stipulates that the relative pause in structural reform; announced at the beginning of 1986, should last for the first two years of the current five-year period, an article in the same issue of World Economic Herald announces that the "relevant departments" are studying the possibility of pushing forward again next year and the year after, in order to resolve the contradictions arising from the simultaneous existence of the old and new systems, and to put the components of the new system in a commanding position at an early date. ${ }^{26}$

Open debate as a method for resolving ideological disagreements inside and outside the Party, as presently recommended by Zhu Houze and others, is of course symbolized by the slogan "Let a hundred flowers bloom and a hundred schools of thought contend!" This formula, originally put forward in China during the Warring States period, and revived by Mao Zedong in 1956, has been once more proclaimed as valid since 1978, but the thirtieth anniversary of the speeches by Mao and Lu Dingyi in May 1956 which marked the beginning of a year of "blooming and contending" in 1956-57 has served as the occasion for several conferences and symposia, and the publication of an unusually large number of extremely bold and forthright articles and speeches on this theme.

Chinese officials and intellectuals of various tendencies have all felt obliged to join in this chorus of praise to the "two hundreds". They include, for example, Hu Sheng, the relatively conservative President of the Chinese Academy of Social Sciences, and close associate of Deng Liqun, who caused extracts from two talks at the Academy in August and December 1985 dealing with this theme among others to be published in Hongqi on 1 May 1986. ${ }^{27}$ The most influential contributions to this debate, however, have come from those who 
wished to use the "two hundreds" to justify the exploration of radically new ideas.

Of the numerous striking statements published in May and June 1986, on the occasion of the thirtieth anniversary, only a few can be quoted here. The first is an article by Yu Guangyuan in which, after recounting in detail the circumstances in which the slogan "Let a hundred flowers bloom, let a hundred schools contend!" was put forward in 1956, he analyses the reasons why, in his view, it has been so little observed during the ensuing thirty years. Among these, he cites Mao's remark at the time that the "hundred schools" amounted in fact to only two schools - the bourgeois school and the proletarian school. In other words, the idea of genuine pluralism within the proletarian or socialist camp was totally foreign to Mao. Yu also referred to the persistent leftist trend since the late 1950's, and the fact that, in those early years, there was no understanding either of socialist structural reform (shehuizhuyi tizhi gaige) or of the importance of opening to the outside world. ${ }^{28}$

Another, and very bold discussion of these issues is that of Su Shaozhi, in which the author begins by pointing out that the abolition of the "two hundreds" slogan was the result of the action of the Qin autocracy, with its goal of "uniformity of thought" (sixiang yizhi). Thus a formula consistently regarded, until very recently, as a socialist ideal and the symbol of the Leninist "Party spirit" was stigmatized as a "feudal relic". Linking the non-implementation of the "hundred flowers" in the 1950's and 1960's to the absence of freedom (including the freedom to make mistakes), and to the absence of socialist democracy, as well as to the influence of the "overly-centralized Stalinist model $^{\prime \prime}$, Su concludes:

"In a socialist country, reform is another great transformation (biange), it is an innovation... There is no precedent in history, and there are no answers to be found in books. We must dare to break the shackles of all traditional things, boldly explore, dare to break through all accepted conclusions, including important individual (gebie) conclusions of Marxism. We must be good at deriving new concepts and drawing new conclusions from real life. This has made new demands in resolutely carrying out the "two hundreds" policy." 29

Another highly significant straw in the wind is the appearance, in one of two symposia on the "two hundreds" reported in People's Daily in June, of a contribution by that very Ma Ding who had been the victim of so much abuse six months earlier. While describing himself as a "young scholar", and expressing 
his desire to learn from his elders, Ma shows no signs of repentance. On the contrary, he calls unequivocally for strengthening socialist democracy and the legal system, and for freedom of creation, research, and scholarship, as well as for equality among scholars and the repudiation of special privileges which allow some to overawe or oppress others. ${ }^{30}$

However striking these and other theoretical developments may be, the crucial issue is, of course, how long the trend inagurated last spring, and which still continues, can endure. The changing intellectual climate can and does influence the prospects of further political change, but in the last analysis it is the reform of the political system which will be decisive. What are the prospects for its continuation?

\section{Political Reform}

Among the various factors affecting this, three can be mentioned here: public opinion, the balance of forces within the leadership, and relations with the outside world.

Although, in the Chinese political system as it exists today, the position of the leadership is undoubtedly the most important factor, the attitude of the Chinese people generally is more important, and less easily manipulated, than it used to be. Chinese public opinion is by no means uniform. It has been shaped, like Chinese society as a whole, by several different sets of values: those of the traditional, pre-modern culture (which the Chinese call "feudal"); those of the capitalist world, to which the country has been exposed mainly before 1949 and since 1978; and the egalitarian and collectivist ethos propagated during Mao's last two decades. The result, as observed last April, is somewhat contradictory. On the one hand, both the traditional disdain for "merchants" (shangren) and Maoist values lead many people to look down on those who engage in "business". For example, young intellectuals told the author that, when buying vegetables from the markets, they would always buy from the peasants, who had brought their own produce to Beijing, and not from intermediaries, who had gone to the countryside and purchased vegetables for resale at a profit in the city. Their view was that the peasants had invested their own labour, and it was therefore legitimate for them to receive a financial reward. "Speculation", on the other hand, was not regarded as a useful contribution to society - even though the press has carried articles arguing that, by supplying needs, such merchants are doing useful work.

On the other hand, in some respects, public opinion is explicitly and sharp- 
ly anti-feudal. The aspect of the current situation which arouses the greatest anger and resentment is probably the frequency with which the children of high cadres themselves become officials, and more broadly the whole idea of a "third echelon" of leaders waiting to take over not only from Deng Xiaoping, but from men in their 70s like Hu Yaobang, and men in their 60s like Zhao Ziyang. Such selection by the previous leaders of their successors is seen as a continuation of the pattern set by Mao, which was in itself marked by "feudal" influences. Hostility to these practices was, in fact, one of the main causes of the incidents of 18 September 1985, for which anti-Japanese sentiments, while they do exist, were in large part a pretext. These events were, however, the work of a number of different currents, each trying to exploit the situation to its own ends, including some groups hostile to the reforms. The motives of these opponents of the current policies are to be found both in the fact that rising prices favour the peasants at the expense of the urban population, and in concern at "unrighteous tendencies". The latter concept, of which so much has been heard since 1985, is however a highly ambiguous one. To the extent that it refers to speculation and profiteering, it might be seen as anti-capitalist, but to the extent that it is aimed at nepotism and the abuse of official position, it might be regarded rather as anti-feudal.

Broadly speaking, it is the author's impression that most Chinese are now in sympathy with the reforms, simply because the overall standard of living is rising. At the same time, the anti-corruption drive has uncovered a number of offenders among the families of those who have shown most zeal in combatting "spiritual pollution", the most notorious case being that of the son of $\mathrm{Hu}$ Qiaomu, recently sentenced to a long prison term for enriching himself through illegal transactions. "This man sets himself up as a teacher of communist morality," many people remark scathingly, "and yet he cannot bring up his own son."

Although instances such as this have undermined Hu's standing, his influence, and that of others in the leadership, such as Chen Yun, Deng Liqun, and Peng Zhen, sceptical about reform and fearful of its consequences remain strong. Thus, to the extent that the direction of policy in the future will depend on the balance of forces in the leadership, the position has not yet been entirely clarified.

It would, as noted earlier, be quite wrong to set up a model of Deng Xiaoping and Chen Yun as polar opposites, and to predict China's future course entirely in terms of which of the two men remains on the scene and in a position of power longer than the other. Though Deng is unquestionably far bolder in 
experimenting with radically new ideas, Chen Yun, too, has called for ceaseless (buduan) advance on the road to reform. But he was careful to add, in his speech of June 1985, that China must only advance along the correct road. The only kind of structural reform China wanted to pursue, he said then, is socialist structural reform, and he called for a resolute struggle against "all erroneous words and actions" contrary to the ideal of communism. ${ }^{31}$ In late January of 1986, Peng Zhen, another representative of the same tendency, denounced ideas opposed to Marxism, by which he plainly meant ideas contrary to traditional interpretations of Marxism, and in particular the article of Ma Ding. ${ }^{32}$

On April 19, speaking to a delegation from Hong Kong, Deng Xiaoping said that for the moment there had been a slight slowdown in the pace, but this was "in order to consolidate and digest the results of the reforms, and to prepare for carrying out even greater reforms in the future". Reform, he said, involved risks, but it was the fruit of deep reflection and study, and must be resolutely pursued. "The heart of the Seventh Five-Year Plan is reform", he declared, adding that within three to five years, the economic system would have been basically adjusted in a way that would assure stability for 60 to 70 years, to the middle of the next century: ${ }^{33}$

On 23 April, Deng told the former Japanese Prime Minister, Fukuda Takeo, that the period of this Five-Year Plan would be of decisive importance in determining whether or not the reforms would succeed. "This road is correct", he stated, "it is the road we must follow, there is no other road we can take". ${ }^{34}$ As long as Deng Xiaoping remains the dominant figure in the leadership of the Chinese Communist Party, there can be no doubt that China will follow this road, though with some zig/zags and occasional calls to order in the ideological realm. But how much does the continuity of Chinese policy, and the stability of the Chinese political system, depend on Deng?

Liao Gailong said to the author in April 1986 in Beijing that, without Deng Xiaoping, there would no doubt have been some process of reform in China after 1976, but it would have developed more slowly, and above all it would not have been so radical and comprehensive. The author discussed this question with a number of other leading Chinese intellectuals, and though there is a natural tendency on the part of Marxists to play down the role of the individual, the author found no one who disagreed with this judgment.

In any case, Deng Xiaoping did launch the reforms in 1978, and after a period of eight years, they have developed a momentum such that, with every further year that passes, it will be more difficult to halt the process. Apart from elite sentiment and public opinion, the process of reform had begun, by 
July 1986 , to involve the promotion of institutional change, in the political as well as in the economic domains. A theoretical symposium on political structure was held from 10 to 12 July at the Central Party School, at the instigation of Deng Xiaoping, ${ }^{35}$ and in July also a "Commission on the Reform of the State Structure" was formed at a very high level..$^{36}$

One of the first published statements on the theme of political reform was that by Wan $\mathrm{Li}$, originally made at a forum on scientific research on $31 \mathrm{July} \cdot{ }^{37}$ The same issue of People's Daily which carried this speech also reprinted, and thus gave added weight to, an article by Su Shaozhi calling, as an important aspect of political reform and of the struggle against China's "feudal" heritage, for recognition of the duty of elected officials to represent their diverse constituencies, with their differing interests and differing ideas, rather than simply repeating a line laid down from on high. ${ }^{38}$

Many more articles about ideological diversity, and about the need for experimentation with political institutions, continued to appear..$^{39}$ In early September, this trend received endorsement at the very top. On 1 September, extracts from Hu Yaobang's talks during a visit to Qinghai were published under the title "Reform has already become an irreversible historical tide". Among his remarks was the statement that Deng Xiaoping's speech of 18 August 1980 was "the programmatic document guiding our reform of the political system." ${ }^{\prime \prime 0}$

For his part, Deng Xiaoping, receiving the chairman of the Japanese Komeito, asserted that "failure to carry out the reform of the political system would obstruct the development of the productive forces". (bugao zhengzhi tizhi gaige hui zu'ai shengchanli fazhan). Pressed by his interlocutor as to whether this whole matter would be resolved at the forthcoming Sixth Plenum, Deng replied that this would be premature, though the subject might be touched upon. "We must be prudent in taking policy decisions," he declared. "Every time we make a step forward, we must see that the possibility of success is relatively great before we make up our minds. ${ }^{\prime 41}$

One can well understand Deng Xiaoping's caution, for the current trend toward intellectual pluralism and institutional reform, however hedged about with safeguards, has potentially revolutionary implications for the Chinese political system as a whole. And yet, the Sixth Plenum, while indeed not spelling out in detail the mechanics of political reform, strikingly confirmed the ideological trends of the preceding six months. 


\section{The Resolution on Socialist Spiritual Civilization}

The Resolution, understandably, stresses the need to take Marxism as a guide in building a socialist spiritual civilization (or, as the new official translation has it, "a socialist society with an advanced culture and ideology"). It is noteworthy, however, that in the long text, there is only one reference to "Marxism-Leninism and Mao Zedong Thought", as against approximately 20 references simply to "Marxism". It has already been noted above that Deng Xiaoping's criticism, in his August 1980 speech, of the Soviet tradition as a source for the autocratic practices of the Maoist era, and the fact that some leading ideologists had traced these defects back beyond Stalin to Lenin himself. There have, in fact, been those in China in recent years who wanted to replace the hyphen in "Marxism-Leninism" by a comma, thus underscoring the point that Leninism was not necessarily the definitive formulation of Marxist thought. Hitherto, such a change, which would have far-reaching symbolic implications, has not been accepted by the Party leadership, but the concentration on "Marxism" in the September 1986 Resolution points in the same direction.

Moreover, the Resolution states that "in many ways our work to promote socialist culture and ideology has not been adapted to the needs of socialist modernization, reform and the opening of the country to the outside world", even though the Party has already "abandoned a series of ossified concepts" in its interpretation of Marxism. While insisting that Party leadership must be upheld, the Resolution states that there can be "no socialist modernization without democracy", and that the "policy-making process" must be "democratized", and given a more scientific basis, in the context of the "two hundreds" policy. Finally, it is stated that "no country can progress if it refuses to accept elements of advanced science and culture from abroad. ${ }^{\prime 42}$

None of these propositions are dramatically new in themselves, and as Deng had predicted a few weeks earlier, the Plenum carefully avoided spelling out in concrete detail what was meant by the democratic reform of the political institutions. Understandably, in view of the fact that high-level official discussion has barely begun, there is as yet no blueprint for political reform analogous to that drawn up by Liao Gailong in his "Gengshen Reform" speech of October 1980. Evoking the need "to reform and perfect the Party and state leadership systems, and to take a step further in extending socialist democracy and improving the socialist legal system", the Resolution declares: "This will be a very complex task. After exhaustive investigation and study, the Central 
Committee will work out plans for accomplishing it, so that political reform may proceed step by step and with proper guidance." ${ }^{43}$

None the less, if one looks at this document as a whole, one cannot fail to be struck by the fact that, if it does not contain all the new ideas which have been put forward in recent months by some of the bolder spirits among the reforming intellectuals, it does endorse, in more prudent terms, many of their views, while containing very little indeed by way of concession to the sceptics fearful of the consequences of reform. The passage just quoted, about proceeding "step by step" after "exhaustive investigation" may be taken to mean that these elements in the Party will be consulted, but that in the last analysis they will not be able to block the progress of the reforms. For, as the Resolution goes on to state, "unless we ... combat all practices that repress and undermine democracy, ... we shall not be able to maintain long-term political stability." The warning is clear.

Perhaps the impact and importance of this resolution can best be assessed in terms of the contrast with the doctrinaire manifesto some elements in the leadership originally intended the Sixth Plenum to produce. But at the same time, the document manifestly reflects a compromise. Deng Xiaoping is too experienced and too skilled a politician not to seek the greatest possible measure of support from the widest possible range of opinion within the Party on each occasion, consistent with the pursuit of his own long-term goals.

Indeed, it is undoubtedly because Deng does play the central and crucial role of arbiter between those more and less enthusiastic about reform, and plays it so authoritatively and successfully, that virtually everyone wants him to remain at his post as long as possible. Deng himself has recently alluded to this on more than one occasion, saying that he wants to retire at the 13th Party Congress next September, but that perhaps people won't let him. ${ }^{44}$

But what if he should not remain in office? Chen Yun and his supporters are powerful men, and their influence remains great. Would Hu Yaobang, Zhao Ziyang, $\mathrm{Hu}$ Qili and others of like mind be able to maintain the momentum of the reforms, if Deng Xiaoping were to go before Chen? It is the author's guess that they would, but it might be a very finely-balanced situation. On the other hand, the cost of another radical change of course, toward a more orthodox Leninist model, in terms of confusion, lost time, and the loss of economic momentum, would clearly be very great, and even those leaders with a certain nostalgia for the 1950's might hesitate to incur such a cost. 


\section{Concluding Remarks}

In drawing up an estimate of the situation and making their choice, the future leaders of China, whoever they may be, will also have to take account of the impact of the current open policies on the country's economic development. During the past seven years, since Deng Xiaoping's visit to the United States in 1979, China has reaped enormous benefits from her growing interaction with the West and with Japan, not only in economic terms, and in terms of technological know-how, but in terms of goodwill. A turn back to a Leninist, or Stalinist model would in large measure sacrifice all that. On the other hand, the present good relationship with the capitalist world brings with it a continuing process of intellectual interchange, which some in the Chinese Communist Party regard as a source of "spiritual pollution", but which is increasingly seen, even by relatively conservative elements in the Party, as in many repects positive.

There is a very great interest on the part of Chinese scholars, including some who formerly took a different view, in problems such as the impact of technological change on society, "systems theory", the "information society", and so on, and an active desire to engage in discussion with foreign scholars on these topics and to integrate the results of such reflection into their own Marxist interpretation of the world in the late 20 th century. In November, even a figure such as Hu Sheng, President of the Chinese Academy of Social Sciences, who is closely associated with Deng Liqun, spoke in favour of such an approach, and of reform of the political system, at a conference in Beijing.

Thus the predominant trends in the economic, political, intellectual and cultural domains are broadly convergent, and serve to reinforce one another. I believe, therefore, that the reform of the economic system, which is unthinkable without the continuation of the open-door policy, and can scarcely go forward successfully without further political reforms, will be maintained for the foreseeable future. 


\section{NOTES}

This is the text of my interpretation of Chinese politics as formulated in November 1986. It has not been revised to take account of developments since that date. For an analysis from the perspective of April 1987, see my introduction to S. Schram, Kaikakuki Chugoku no ideorogii to seisaku 19781987 (Tokyo: Sososha, 1987), pp. 11-28.

1 This first section is, in large part, a summary of the argument I put forward in 1984 in my article "Economics in Command?" Ideology and Policy Since the Third Plenum, 1978-1984". The China Quarterly, No. 99 (September 1984), pp. 417-461. For that reason, individual statements and quotes are, in general, not footnoted.

2 Deng Xiaoping, "On Special Economic Zones and Opening More Cities to the Outside World", February 24, 1984; in Deng Xiaoping, Build Socialism with Chinese Characteristics (Beijing: Foreign Languages Press, 1985), pp. 2527.

3 "Benbao pinglunyuan" (People's Daily Commentator), "Lilun yu shiji" (Theory and reality), Renmin ribao, December 7 , 1984.

4 Renmin Ribao, December 30, 1984.

5 Renmin Ribao, March 29, 1985.

6 Guangming Ribao, April 13, 1985.

7 Renmin Ribao, April 14, 1985. This speech may well have represented a tactical concession on Hu Yaobang's part, since he had been sharply criticized (and according to some reports obliged to make a self-criticism) because of the impression created by his 7 December article.

8 Hongqi No. 19, 1985, pp. 32-36; Beijing Review, 1985, No. 39, pp. 15-20.

9 Renmin Ribao, January 1, 1986.

10 Renmin Ribao, February 9, 1986.

11 Renmin Ribao, January 27, 1986.

$12 \mathrm{Ma}$ Ding, "Ten Major Changes in China's Study of Economics", Beijing
Review, 1985, No. 49, pp. 17-20. (This version had been revised and expanded as compared to that originally published in Gongren Ribao).

13 Cited by Tang Tsou in "Marxism, the Leninist Party, the Masses and the Citizens in the Formation and the Structure of the Communist Party-State in China", in S. Schram (ed.), Foundations and Limits of State Power in China (London: SOAS and Hong Kong: The Chinese University Press, forth-coming, spring 1987).

14 Renmin Ribao, March 28, 1986.

15 Compare the Seventh Five-Year Plan (text in Renmin Ribao, April 15, 1986), especially Section 8, par. 44, with the Decision of October 1984 (translation in Beijing Review, 1984, No. 44, insert), especially Section III, p. VI.

16 Renmin Ribao, April 14, 1986.

17 See, for example, the article of He Jianzhang, "Shangpin jingji shi shehuijingji fazhan buke yuyue de jieduan" (Commodity economy is an inevitable stage in socio-economic development), Renmin Ribao, May 23, 1986, which stresses that commodities, contrary to what has commonly been thought, are in no way specifically linked to capitalism.

18 Renmin Ribao, July 1, 1986; translated in Beijing Review, 1986, No. 28, pp. 1213,32 .

19 Renmin Ribao, April 24, 1986. (Talks of April 17 and 19).

20 Renmin Ribao, April 22, 1986.

21 Renmin Ribao, April 15, 1986.

22 Renmin Ribao, April 25, 1986. Zhu Houze had, in fact, already spoken up prudently but forcefully in favour of relaxed and open discussion of all sorts of views, saying that the Propaganda Department of the Central Committee was not an academy qualified to decide literary and theoretical questions. See his talk of March 9, 1986, published in Dus$h u, 1986$, No. 6, pp. 3-10. 
23 Shijie Jingji Daobao, April 21, 1986, pp. 1-2.

24 Shijie Jingii Daobao, April 7, 1986.

25 Shijie Jingii Daobao, April 21, 1984, p. 14.

26 Shijie Jingii Daobao, April 21, 1986, p. 3.

27 Hu Sheng, "Guanyu jiaqiang shehuikexue yanjiu de jige wenti" (Some problems in strengthening social science research), Hongqi, 1986, No. 9, pp. 3-11.

28 Renmin Ribao, May 16, 1986.

29 Su Shaozhi, "Shuangbai' fangzhen sanshinian" (Thirty years of the 'two hundreds' policy'), Wenhui Bao, May 15, 1986.

30 See the reports of a symposium held on May 29, in Renmin Ribao June 13, and of one held on May 31, in Renmin Ribao of June 20, 1986. The article by Ma Ding appears in the first of these.

31 Chen Yun, Zai quanguo dangfeng gongzuo jingyan jiaoliuhui shang de jianghua (Speech at the national conference regarding work on Party style), June 29, 1985, (Beijing: Renmin chubanshe, 1985), 4 pp.

32 Renmin Ribao, April 5, 1986, p. 3.

33 Renmin Ribao, April 20, 1986.

34 Renmin Ribao, April 24, 1986.
35 Dagongbao (Hong Kong), July 16, 1986; summarized in SWB, FE/8315/BIl/1, July $19,1986$.

36 Liaowang, July 21, 1986; extracts in SWB/FE/8317/BII/1, July 22, 1986.

37 Renmin Ribao, August 15, 1986.

$38 \mathrm{Su}$ Shaozhi, "Zhengzhi tizhi gaige yu fandui fengjianzhuyi yingxiang" (Reform of the political system and opposing feudal influences), Renmin $R i$ bao, August 15, 1986.

$39 \mathrm{See}$, in particular, the editorial "Zhengzhi wenti keyi taolun" (It is permissible to discuss political issues), Renmin Ribao, August 30, 1986.

40 Talks of August 19 and 27; Renmin Ribao, September 1, 1986.

41 Renmin Ribao, September 4, 1986.

42 Beijing Review, 1986, No. 40, insert, pp. I-VIII.

43 Beijing Review, 1986, No. 40, p. V.

$44 \mathrm{See}$, for example, his interview with Mike Wallace of CBS on 2 September (Beijing Review, 1986, No. 38, pp. 4-7), in which he stated: "I am trying to persuade our people to let me retire at the Party's 13th National Congress next year. ut so far, what I have heard is dissenting voice[s] all around." 